\title{
Literatur
}

Berthold, P. (1990): Vogelzug. Eine kurze, aktuelle Gesamtübersicht. Darmstadt. BerThold, P., J. Griesinger, E. Nowak \& U. Querner (1991): Satelliten-Telemetrie eines Gänsegeiers (Gyps fulvus) in Spanien. J. Orn. 132: 327-329. - Berthold, P., E. NowAK \& U. QUERNER (1992): Satelliten-Telemetrie beim Weißstorch (Ciconia ciconia) auf dem Wegzug eine Pilotstudie. J. Orn. 133: 155-163.

Nowak, E., P. BerThold \& U. Querner (1990): Satellite tracking of migrating Bewick's Swans. A European pilot study, Naturwiss. 77: 549-550.

\section{Nachweis eines Dünnschnabel-Brachvogels (Numenius tenuirostris) aus Algerien}

\author{
Eugeniusz Nowak
}

Nowak, E. (1995): Record of the Slender-billed Curlew (Numenius tenuirostris) from Algeria. J. Orn. 136: 76. - In October or November 1983 one specimen of the Slender-billed Curlew, shot at and wounded by a hunter near the city of El Kala $\left(36^{\circ} 55^{\prime} \mathrm{N}, 8^{\circ} 25^{\prime} \mathrm{E}\right.$ ) was brought to the University of Annaba. After having died, it was prepared as a skin for the scientific collection of the University.

Bundesamt für Naturschutz, Konstantinstr. 110, D-53177 Bonn

Der algerische Doktorand Tagar Ali brachte im Herbst 1983 (Oktober oder November) in die zoologische Abteilung der Universität der Stadt Annaba ein in der Nähe der Ortschaft El Kala ( $\left.36^{\circ} 55^{\prime} \mathrm{N}, 8^{\circ} 25^{\prime} \mathrm{E}\right)$ angeschossenes Exemplar des Dünnschnabel-Brachvogels, das kurze Zeit später starb. Die Fundstelle liegt in der Nähe anderer Beobachtungsorte des Dünnschnabel-Brachvogels der letzten 18 Jahre in Algerien (vgl. GretTon, 1991: 5, 8, 151) sowie etwa $100 \mathrm{~km}$ östlich von der Stelle, wo 1866 ,ungeheuere Scharen, so groß wie Starenschwärme" (TACZANOwSKi 1870) gesichtet wurden.

Der Balg des Vogels aus El Kala wurde der Universitätssammlung übergeben. Den Vogel hat gesehen und seine Art-Zugehörigkeit bestimmt u. a. E. G. YAvrouYan (Leiter des Lehrstuhls für Zoologie der Universität Erevan, Armenien), der zu dieser Zeit Gastprofessor in Algerien war. Auf Grund seiner Mitteilung (während der 4. Vertragsstaaten-Konferenz der Bonner Konvention in Nairobi am 10. Juni 1994) wurde diese Notiz verfaßt. Eine Anfrage, ob das Präparat noch heute existiert, blieb unbeantwortet.

\section{Literatur}

Gretton, A. (1991): Conservation of the Slender-billed Curlew (Numenius tenuirostris). ICBP, Cambridge.

TACZANowski, L. (1870): Úbersicht der Vögel, die in Algerien, Provinz Constantine, während der Reise von Ende November 1866 bis Ende April 1867 gesammelt und beobachtet wurden. J. Orn. 18: 33-56. 